\title{
Law: A Tool for Measuring Human Conduct and Socialization
}

\author{
Olivia Anku-Tsede ${ }^{1}$ \\ ${ }^{1}$ University of Ghana Business School, Legon, Accra, Ghana \\ Correspondence: Olivia Anku-Tsede, University of Ghana Business School, P. O. Box LG78, Legon, Accra, \\ Ghana. E-mail: oankutsede@ug.edu.gh
}

Received: May 24, 2013 Accepted: June 14, 2013 Online Published: August 30, 2013

doi:10.5539/jpl.v6n3p169 URL: http://dx.doi.org/10.5539/jpl.v6n3p169

\begin{abstract}
This article seeks to examine the meaning and content of law as perceived by some scholars to aid in the determination of whether the primary aim of law is to measure human conduct and facilitate socialization. Law is a phenomenon that has attracted several and diverse definitions from different schools of thoughts. As a social phenomenon its definition seems to be dependent and influenced by the socio-cultural experiences of the relevant proponent and thus subjective. This article critically examines various definitions of law, in a bid to unravel the true and proper meaning of law. It shows that law is not merely a tool for enforcing orders of the state or a superior being but primarily a tool for measuring human conduct and socialization.
\end{abstract}

Keywords: law, socialization, theories of law

\section{Introduction}

This article seeks to unravel the true meaning and content of law as perceived by some scholars to aid in the determination of whether the primary aim of law is to measure human conduct and facilitate socialization. Law is a phenomenon that has attracted several and diverse definitions from different schools of thoughts as well as legal theorists. As a social phenomenon its definition seems to be dependent and influenced by the socio-cultural experiences of the relevant proponent. There have been several definitions of law propounded by scholars with various traditions, socio-economic backgrounds and belonging to various distinct schools of thoughts.

It appears these definitions and legal concepts are often influenced by such socialization process and historic backgrounds of the proponents. Existing definitions and content of law are thus subjective and clouded by individual personal experiences and observations of each legal theorist. The true meaning of law has to date been lost on both scholars and students of law as none of the propounded theories and definitions of law is devoid of personal experiences and historic development, thus failed to provide a holistic view of law. This article, thus critically examines various definitions of law, in a bid to unravel the true and proper meaning of law. It shows that there can be a true and generic meaning of law without any influence from historical developments and socio-cultural experiences. This article establishes that law is not merely a tool for enforcing orders of the state or a superior being but primarily a tool for measuring human conduct and socialization.

\section{Law and the State}

Law, however so described, either as a doctrine, concept, body of dogma, a theory or an instrument, has over decades been given so many meanings and descriptions. It appears to have so many facets and different variables serving several purposes and needs. Law is full of phraseologies obtained from the sphere of morality and by the strength of language, it has been conceived under different and several names without perceiving it, unless steps are taken to confound it (Holmes, 1997:993). The term 'law' has been defined as denoting governmental social control (Black, 1972), whilst the term government was expressed as a hierarchical organization that is widely regarded as having the legitimate authority to inflict detriments on persons, within its geographical jurisdiction and who have not voluntarily submitted themselves to its authority (Michelman, 1977). Black's (1972) definition of law appears to denote a controlling, compelling and sanctioning power of the state through legislations and regulations providing for the behavioral patterns of individuals and groups of society as well as a mechanism for sanctioning and compelling compliance in the event of a deviation.

The term government, as described by Michelman (1977) appears to limit the functionality of the state to a tool for the infliction of detriment through law. This definition, however, fails to recognize other compelling attributes of a government, such as representing an institution providing for the effective management of the business of a state. 
For instance, a contract can be legally enforced through the state by making available its coercive powers to a contractual party where one fails to perform its contractual obligations and the rules providing for the use of the state's coercive power constitutes the law of contract. The law of contract therefore enables individuals to use the state's coercive powers for their own personal ends. To this end the state can be described as an enforcement machine possessing matchless powers of compulsion (Kronman, 1985). It is this coercive power of the state that individuals or group of individuals may appropriate through the legal system to compel the compliance of contractual terms.

Even though coercive power similar to that of the state exist in many other human institutions which are not states, the mere existence of such power in these human institutions does not qualify them as states and therefore cannot be appropriated for the purpose of contractual enforcement. Accordingly, the distinguishing feature of a state from any other human institution does not lie in the existence of coercive power but the outward existence of the concentration of power in the hands of a separate class of people (Lenin, 1895:419). A state is therefore a historical occurrence limited by the boundaries of class society and constituted as a mechanism for the domination of one class over the other with a composition of members made up of the ruling class controlling the powers of coercion and suppression (Pashukanis, 1932:10). Consequently, it is this distinctive and superior power of coercion and suppression concentrated in the hands of a certain group of people that can be appealed to by a contracting party to enforce a transaction or compel the compliance of contractual terms. The state usually serves as the sole source and controller of rights, obligations and entitlements, creating order and social control in any given society whilst the government generally serves as the sole maker of operative rules, regulations and contractual rights backed by the force of the state (Coase, 1960:9). This proposition seems to follow that of Hobbes (1909), a proponent of the theory of law and society, who proposed that, without a Leviathan (government) to issue and enforce commands, all would be endless civil strife and chaos. In his words, Hobbes (1909) expressed that, there would be

...continual feare, and danger of violent death; And the life of man, solitary, poor, nasty, brutish, and short... To this warre or every man against every man, this is also consequent; that nothing can be Unjust. Where there is no common Power, there is no law; where no Law, no Injustice... It is consequent also to the same condition, that there be no Propriety, no Dominion, no Mine and Thine distinct; but only that to be every mans that he can get; and for so long, as he can keep it...

The state is the ultimate mechanism of social control in society and this power of control is evidenced through its monopoly of the legitimate use of physical force as a means of domination whilst the use of this force by other individuals or institutions is limited to the extent to which the state permits (Weber, 1958). Accordingly it is only a state that can compel the compliance of contractual terms or covenants entered into by private contracting parties using its legitimate force through the application of law. The concentration of the powers of enforcement in the state through the use of legitimate force is often exhibited both in the spirit and letter of most countries' Constitutions. An examination of the constitutional provisions of countries like the United States, Nigeria, Australia, United Kingdom, South Africa and Ghana, one of the youngest Constitutions, shows that whilst some Constitutions seem to approve the use of such powers through a class of people, a few others believe in the concentration of such powers in a sole source (United States Constitution, 1790, The Commonwealth of Australia Constitution Act, 1900, Constitution of Nigerian, 1999, Constitution of South Africa, 1996, Constitution of Ghana, 1992 and the Constitution of the United Kingdom). For instance, the United States (US) Constitution of 1790 vests the ultimate power for the administration of justice in the Supreme Court, and such inferior courts as the Congress may from time to time ordain and establish. Although the US Constitution vests the judicial power in the judiciary, the preamble to the Constitution expressly recognises the relevance of the people to the validity of the exercise of such powers, thus making the judicial body accountable to the people. The preamble to the US Constitution provides as follows:

"We the people of the United States, in order to form a more perfect union, establish justice, insure domestic tranquility, provide for the common defense, promote the general welfare, and secure the blessings of liberty to ourselves and our posterity, do ordain and establish this Constitution for the United States of America."

Whilst the South African Constitution of 1996 by virtue of section 165(1)(2)(3) vest the power of judicial administration in the judicial arm of government, the Constitution requires that such power be controlled by their loyalty, not only to the Constitution but the Republic and its people(Section 41(1)(d) of the South African Constitution of 1996). The preamble to the said Constitution confirmed this when it pronounced that:

"We, the people of South Africa, Recognise the injustices of our past; Honour those who suffered for justice and freedom in our land;... We therefore, through our freely elected representatives, adopt this Constitution as the supreme law of the Republic so as to-...Heal the divisions of the past and establish a society based on democratic 
values, social justice and fundamental human rights. Lay the foundations for a democratic and open society in which government is based on the will of the people and every citizen is equally protected by law;...".

In Nigeria, even though the 1999 Constitution confers the Legislative, Executive and Judicial powers of the Federation on the national assembly, the president and the courts respectively, the preamble to the Constitution recognises that such powers are granted by the State, thus, the people. Contrary to the theory of law as propounded by Pashukanis (1932), section 1(1) (2) and (3) of the Nigerian Constitution reiterate the binding force of the Constitution and makes the concentration of power in the hands of a class or group of persons an illegality. Particularly, section 1 (2) stipulates that: "The Federal Republic of Nigeria shall not be governed, nor shall any persons or group of persons take control of the Government of Nigeria or any part thereof, except in accordance with the provisions of this Constitution"

Similarly, the 1992 Constitution of Ghana vests the powers of the administration of justice in the judiciary, an arm of the Ghana government,. Pursuant to the powers vested in the judiciary, the courts may issue such orders and directions as may be necessary to ensure the enforcement of any judgement, decree or order. Even though the Constitution grants the power of administering justice to the judiciary, it recognises the inherent power vested in the people of Ghana (Article 126 (4, 125 (1) and (5).. This recognition is expressed under article 125 (1), where it clearly states that; Justice emanates from the people and shall be administered in the name of the Republic by the Judiciary ...". To avoid any confusion regarding the extent of the powers vested in the people, the Constitution of most countries, like the US, UK, Nigeria and Ghana, provide for how these powers may be exercised. Consequently, citizens may exercise popular participation in the administration of justice through institutionalised systems. For instance, the United Kingdom, United States, Ghana, amongst others have adopted the the jury and assessor systems (United States Constitution of 1790, Criminal Procedure Code of Ghana, 1960 (Act 30), The Juries Act of the United Kingdom, I974, Criminal Procedure Act of the Federation of Nigeria, 1990). The nature of the legal systems of these countries is such that they are not limited to the concentration of power in a class of people, as championed by Pashukanis (1932). They neither follow the legal centralist school of thought nor represents a system where controlling powers emanates from a sole source, that is government, as propounded by Hobbes (1909).

The above notwithstanding, it is prudent to note that, to the extent that the exercise of the powers of the people is provided for and spelt out by the various constitutions and the exercise of which are carried out through public institutions, and the jury system, the exercise of the peoples' powers is regulated by law and hence backed by the force of the state. To this end the law determines the behavioural patterns of individuals, institutions and the society at large. To show that law has a broader role to perform in society, hence serve more as a tool for measuring conduct and socialization, Turk (1976) indicated as follows:

"An all encompassing and practical as opposed to theoretical definition of law may include the control of the means of direct physical violence as in the use of the police or the judiciary to support one's claim in a conflict, control of the means of production, allocation or use of material resources, control of decision-making processes, control of definitions of and access to knowledge, beliefs and values as in ideological power and the control of human attention and living-time as in diversionary power".

The concept of law as elaborated by Turk (1976) gives a broader and in-depth view of law and clearly identifies the controlling and compelling power of law. It also identifies the means by which law can be used to compel the compliance of an order or the fulfillment of an obligation and exhibits the enforcement power of state officials, thereby maintaining order in society and reducing conflicts. As per his definition, legal concepts and thought-ways are also developed as a means of comprehending and finding solutions to societal problems arising out of social interactions and attempts of members of society to dominate. In practice therefore law purports to measure conduct as a means of controlling social deviants and thereby facilitates socialization. This aspect of law is made evident in its ability to define and provide access to knowledge, beliefs and values.

Although, Turk (1976) gave a broader and elaborate view of law, it cannot be disputed that the work of Max Weber (1954) is the single most influential classical contribution to the sociological study of law. Not only does Weber's work count amongst the most significant and foundational developments in sociological thinking, it also devotes very substantial and elaborate attention to the role and evolution of law in society. In his Politics as a Vocation Weber (1919) conceived the state as the monopoly of the legitimate use of physical force. To him, the state is that entity which upholds the claim to the monopoly of the legitimate use of physical force in the enforcement of its orders. He defines the state as a community successfully claiming authority on legitimate use of physical force over a given territory. He argued that the police and the military are the state's main instruments for the exertion of 
public force. He conceded, however, that private force could also be adopted as long as its legitimacy is derived from the state.

It appears some countries' constitutions have adopted the reasoning in the Weber's (1919) theory of law. This is because most states seem to recognize the legitimate use of both public and private force, in certain circumstances, in the protection of personal and other rights (United States Constitution, 1790, The Commonwealth of Australia Constitution Act, 1900, Constitution of Nigeria, 1999, Constitution of South Africa, 1996, Constitution of Ghana, 1992, Constitution of the United Kingdom). Turk's theory, though analyses law as a tool for compelling, fulfilling and enforcing orders or obligations, it appears to limit law to the exercise of power by state officials.

The legal centralistic view, championing the theory that the state possesses the sole source of coercive power supports a theoretical error that could be traced to Hobbes (1909). This may be so, as the theory is based on a concept denoting that rules and controlling powers emanate from one source only; the state. It however ignores certain basic controlling factors, such as inherent personal attributes and beliefs that control a person's behavior and determines how a person may react to another under certain circumstance without any regard to laws or regulations issued by the state. Such inherent attributes and beliefs may also reduce transaction cost without any reference to the law of contract. This legal centralist view is limited to laws, rules and regulations issued by a government and make no reference to customs and traditions which has developed over a period of time and in accordance of which a community may regulate conduct between members.

The importance of history and tradition in the determination of what constitutes law cannot be over emphasized as they provide the reason for which a rule of law may have taken a particular course or why that rule exist at all. The rational study of law is to a large extent the study of history, as it provides the precise scope and nature of rules and justifies the worth of a rule (Holmes, 1997). In attributing the source of societal and individual rights and conduct controlling power to the sole authority of the state, Coase recognized that there are other, albeit small and subject to checks, source of controlling powers which may achieve equally good controlling results but at a higher cost. Further, governmental control or the delimitation of rights by the state and its enforcement through legal means, even though backed by the force of the state may not necessarily give a better result than the operations of market forces (Coase, 1960). Even though the role, importance and effectiveness of a state in the enforcement of contracts have been overstretched, the power it exhumes in backing legal enforcement mechanisms cannot be overlooked and one cannot initiate a legal process and successfully enforce a contract without falling on the incontrovertible power and force of the state.

\subsection{The Sociological Perspective}

The sociological view point consists in observable acts and not rules or norms as used in jurisprudence and everyday language. Sociologists believe that law is not what the legal world regard as binding or obligatory, but rather the observable dispositions of judges, policemen, prosecutors or administrative officials (Black, 1972). Consequently law in accordance with sociological belief is simply a behavioral pattern, but so is norm. In sociological language norm or rule is used to refer to a behavioral pattern of some kind (Durkheim, 1953). The definition of law as given by sociologists is therefore no different from norms and rules. The sociological point of view therefore fails to provide a definitive or conclusive concept of law as it limits law to that which is not norm or rule.

Black's perception of law as consisting of observable acts and not rules is very much inconsistent with his definition of law as governmental social control. In one vein he speaks of law as a controlling element emanating from a source and in another, describes it as a thing that can be observed or obtained empirically. It is suggestible therefore that Black fails to recognize the use of legal doctrines and reasoning in the explanation of law. Law is a normative discourse and legal doctrine being the language of law provides the relevant vocabulary (Frankford, 1995). Legal doctrines such as rules, regulations, legislations, rights and obligations cannot be separated from the concept of law, as it is an inseparable and integral part of law strictly so called. His concept of law fails to connect the theory he tries so hard to develop to the reality as is seen through even what he terms "observable acts".

In his theory of law, Kelsen (1957) conceived of law as norms. He believes his theory of law is pure because his concept of law is not derived from external substance and is devoid of any substantive meanings or material elements. In determining the validity of legal norms, he identified the justification for each individual legal norm as traceable to the basic norm through a hierarchy of norms. According to his theory, the validity of the legal norm is established by appeal to the appropriate higher-level-norm, whose own validity is established, in turn, by appeal to its higher level. This tracing is done through to and until the highest level of norm in the legal system is reached and this is usually the constitution. An appeal is further made from the constitution to an earlier constitution through to the first historical constitution. The establishment of the validity of a legal norm therefore ends with the 
first historical constitution, as the constitution is itself the highest source from which all other lower norms are derived and there is therefore no further appeal to any higher level of positive or natural law. Consequently, the validity of the Constitution can only be derived from a non-legal norm which he terms the basic norm (Kelsen, 1992). In his words, Kelsen (1945) stated that; "The basic norm ...... is nothing but the fundamental rule according to which the various norms of the order are to be created".

Kelsen's theory therefore presupposes a basic norm which confers validity to the framers of the first constitution and thereafter on all legal systems deriving validity from this first constitution. Even though the basic norm is an authorizing norm, granting validity to all lower norms, it is in itself neither a man-made norm nor created by any legal authority. It is a hypothetical foundation, a mental presupposition and a product of thought that does not describe an existing situation (Kelsen, 1934; Paulson, 1992). Kelsen's theory of law, however fails to provide a clear understanding of law as the search of the grund norm seems to go ad infinitum without a clear end existing only in theory without any proof of its applicability in practice. Vaihinger (1935) observed that, the basic norm cannot even qualify as a hypothesis as a hypothesis is usually based on assumptions which could be verified by empirical evidence. Unfortunately the basic norm could not be verified by any empirical evidence and therefore false as reality does not agree with it. It can only be described as a fictitious concept as its existence cannot be verified. As a result of the fictitious nature of the basic norm, the theory could not be defensible leading to the overturn of the Pure Theory of Law as propounded by Kelsen (Paulson, 1992). But for the absence of an explicit justification and source of the basic norm, Kelsen's theory of law and the legal norm would have been the closest and true theory to the explanation of law. It seems to have been the most pure theory of law ever developed as it relies on strictly pure legal concepts without any reliance on any socio-historic factors.

The above notwithstanding, Kelsen's pure theory of law has achieved a certain notoriety in jurisprudence. This notoriety arises from its use by the courts of some sovereign jurisdictions in analyzing difficult political and constitutional issues created in the aftermath of revolutions.

For instance in the 1958 case of The State v. Dosso, P L D 1958 S C (Pak.) 533 where an annulment and abrogation of the Constitution was made by a successful military revolution leader, the court was of the view that;

"where a Constitution and the national legal order under it is disrupted by an abrupt political change not within the contemplation of the Constitution, then such a change is a revolution and its legal effect is not only the destruction of the Constitution but also the validity of the national legal order, irrespective of how or by whom such a change is brought about"

The pure theory of law gained some recognition in the above case when Qaiser Khan, J. indicated that:

"A Constitution or the basic norm could be annulled, abrogated, destroyed or suspended in two ways, one by a Constitutional act, that is to say, by the method provided for in the Constitution for changing or replacing it and the other by an un-Constitutional act, say revolution or coup d'etat, which is known as extra-Constitutional act. In the instant case the Constitution of 1973 was put in abeyance, that is to say, suppressed for the time being by the Chief of the Army Staff by an extra-Constitutional act of issuing a Proclamation declaring himself as the Chief Martial Law Administrator. ........ Now the validity or invalidity of this action could not be tested on the basis of the Constitution of 1973 as it was no longer there having been suppressed and there was no other superior norm on the basis of which it could be tested. ".

The Ugandan case of Uganda v. Commissioner for Prisons, ex parte Matovu, 1966 E.A, took recognition of the decision in the State v. Dosso's when it held that;

"Applying the Kelsenian principles, which incidentally form the basis of the judgment of the supreme court of Pakistan .........., our deliberate and considered view is that the 1966 constitution is a legally valid constitution and the supreme law of Uganda, and that the 1962 constitution having been abolished as a result of a victorious revolution in law does no longer exist nor does it now form part of the laws of Uganda it having been deprived of its de facto and de jure validity. The 1966 constitution, we hold, is a new legal order and has been effective since April 1966 when it first came into force".

The theory of law as applied in the above cases was declared wholly unsustainable in the Pakistan case of Miss Asma Jillani v. Government of Punjab \& Anr, P L D 1972 Supreme Court 139, where it was held to be wholly unsustainable and cannot be treated as good law either on the principle of stare decisis or otherwise. According to the court, the proclamation of martial law does not by itself involve abrogation of civil law and functioning of civil authorities and certainly does not vest the Commander of the Armed Forces with the power of abrogating the 
fundamental law of the country. Accordingly the commander of Armed Forces is bound by his oath to defend the constitution.

The court in State v. Dosso which laid down a novel juristic principle of far reaching importance seemed to have misconstrued the theory of law as propounded by Kelsen. A critical examination of the pure theory of law suggests that Kelsen did not establish a principle of legal theory of general or universal application but merely traced the source of a higher order giving validity to a certain legal system. He sought to identify what law is and the legitimacy of law.

In contrast to the above cases, the Privy Council in Madzimbamuto v. Ladner Burke (1978) 3 WLR 1229, held that the 1965 constitution was not valid since it had not been made by lawful means and Mr. Smith's Government was not in full and effective control of Southern Rhodesia. The Privy Council thus failed to recognize the terminating effect of a revolution on a civilian and constitutional government. It seems the Privy Council in making its decision did not accept the universal application of the pure theory of law, particularly when it involves an unconstitutional overthrow of a lawful civilian government.

It appears the pure theory of law as propounded by Kelson failed to consider the sociological factor of moral values and justice as was seen in the case of Begum Nusrat Bhutto v. The Chief of The Army Staff \& Federation Pakistan, PLD1977, SC 657. The Supreme Court in this case unanimously held, dismissing the detention petition as not being maintainable. The court observed that Kelsen's pure theory of law is not universally accepted, and is not consistent for full application in all revolutionary situations. Accordingly, the theory is open to serious criticism on the ground of excluding from consideration sociological factors of morality and justice. Legal consequences of an abrupt political change by imposition of Martial Law have to be judged not by application of an abstract theory of law in vacuum but by the consideration of total milieu preceding the change. According to the court, the theory has no relevance where breach of legal continuity is admitted or declared to be of a pure temporary nature and for a limited specific purpose because such phenomena is one of theory to such transient and limited change in the constitutional continuity of a country is inappropriate.

A divergent dimensional definition of law is that by Karl Marx (1818-83) and Freidrich Engels (1820-95) (Note 1). Marx's theory and analysis of law places more importance on the power of economic forces in society rather than on the concept of an impartial and neutral rule of law. He believed that the material forces of a society and those that control these forces shape the society's legal system. Marx's theories about society, economics and politics, collectively known as Marxism hold that human societies progress through class struggle: a conflict between an ownership class that controls production and a proletariat that provides the labor for production. He called capitalism the "dictatorship of the bourgeoisie," believing it to be run by the wealthy classes for their own benefit; and he predicted that, like previous socioeconomic systems, capitalism produced internal tensions which would lead to its self-destruction and replacement by a new system, known as socialism. He argued that society would be governed by the working class in what he called the "dictatorship of the proletariat", the "workers' state" or "workers' democracy". He believed that socialism would eventually be replaced by a stateless, classless society called communism. Along with believing in the inevitability of socialism and communism, Marx actively fought for the former's implementation, arguing that social theorists and underprivileged people alike should carry out organised revolutionary action to topple capitalism and bring about socio-economic change (Random House, 2005, Ologies \& Isms, 2005).

Essentially, law is a form of life which can be explained not by using scientific means but by the use of social forces of society. The social foundation of law is therefore not found in the rule of law as provided by legislators and jurists but rather found in the workings of society itself. Social forces, and not the rule of law, therefore dictate the legal order of societal institutions. Most sociologists in their attempt to decipher what law is concentrates only on the rule of law and not the legal order resulting from the workings of social forces (Ehrlich, 1916). The myth surrounding what law is and ought to be and the foundations thereof could therefore be more complete if socio-legal theorists attended to the forces of society creating the legal order in addition to the components and sources of the rule of law. Accordingly, Ehrlich saw law as being all social control mechanisms and regarded it more as a theory of social control by the forces of society. Ehrlich's (1916), concept of law differs from other jurists, theorists of law and society and jurisprudence in that as the others perceived of law as a body or authoritative rules and decisions, Ehrlich conceived of it as the legal order dictated by the relations making up the legal order, the body of norms of conduct and the functional legal precepts. His approach relied on the legal order made up of the body of norms of decision to the inner order of associations and relations making up society (Pound, 1943). 
In finding justification for the perception of law by the champions of the sociology of law, Pound (1943) thought that their reason may be based on law functioning as an instrument in the shaping of human conduct to enable organized collective action and individual behavior to be in harmony with the spiritual values of the noetic mind. This reason is however not enough to justify the sociologists' theory of law as law in its true meaning has more to it. Law may be used as a tool for societal control but cannot by any stretch of imagination both in scope and strength be equal to social control. It is more than a social control mechanism. By its true definition, law "must reconcile the conflicting spiritual values of the collective mind in such a way as to bring about an orderly system of conduct" (Gurvitch, 1942 as cited in Pound, 1943).

Unfortunately, in Gurvitch's (1942) attempt to differentiate the true meaning of law from the sociologist view point, he also in substance used law to refer to other social control mechanisms (Pound, 1943:12), which fails to bring to light the true distinction between his perception of law and that of sociologists. Proponents and followers of the law of nature on the other hand believe that society was created by a social contract and that law was only a consequence of this contract. Since this social contract was the same everywhere on earth it follows therefore that natural law was the same everywhere and formed the basis of municipal law. A departure of the municipal law from the principles of natural law destined a miscarriage of justice (Ehrlich, 1916). Natural law theorists however failed to state what really constitute law or as in their case natural law but rather attempted at giving a not too clear description of what natural law is.

The moral functionalist theorists conceive of law as a means of resolving or preventing disputes. This conception is however incomplete and lacks all the attributes of law as it is and ought to be, since it restricts the concept of law to conflict resolution and prevention mechanism. It also fails to recognise laws' coercive, disruptive and exploitative nature. The very nature of the moral functionalists' definition encourages research in which other theoretical assumptions such as natural law and functional-systems are ignored (Turk, 1976:276). Further the moral functionalist concept of law does not take into account the legal order within which the system operates. The whole concept of law as propounded fails to account for the operation of the legal system and the controlling power of law.

Law has also been thought of as political institutions and hardened customs that formulated rules of the dead over the living (Spencer, 1882). This observation of law presents law as being slow to change and unable to follow the pace of change in society. It denotes a static institution and therefore not fit for a dynamic society, which is what we live in today. This perception however limits law to its negative side and fails to consider the power of law to control deviant behavioral patterns of society. It neither gives room for laws' ability to provide a means for dispute settlement nor force to compel the compliance with orders and the fulfillment of contractual obligations.

Another facet of the whole concept of law is that it is described as the witness and external deposit of moral life and shares the same history with moral development of society. The practice of law, in spite of its limits has the propensity of turning men into good citizens. Law is not morality but it's affected and limited by morality. Morality deals with the actual internal state of a person's mind, that is, what his intentions are, whilst the law deals with the external exhibition of signs. The court in determining the existence of a contract will not only look at the actual intentions of the parties but will be swayed by the reasonableness of the external signs or conduct exhibited by the parties. In fact, law is simply "the prophecies of what the courts will do in fact, and nothing more pretentious...." (Holmes, 1997).

Law can also be described as a certain unknown or fully undisclosed rules of culture which are nevertheless accepted by society. These are usually deeply rooted cultural beliefs and values which are generally accepted and obeyed without their being declared as such. They include standardized and generally accepted rules developed through various gestures or sound and normally comprise of rules of knowledge, convenience, technology and common life. Law is further referred to as rules of conduct governing relations between individual members and amongst members of groups in society. Such rules may be developed to create orderliness in society by controlling certain behavioral patterns and elements of social deviance. It is said to constitute a specific mechanism created to deal with disputes or claims and composes of societal generally accepted rules as in the sense of establishing a retributive and restitutive social action (Malinowski, 1942).

In contrast to various concept of law developed on propounded theories outside classes and socio-economic developments, the Marxist perception of law is based on concrete historical meanings of law derived from class societies and socio-economic formation. It is alleged to be an impossible task to undertake a search for a general meaning of law without first considering the law of socio-economic formation of society and it is only by so doing that one can identify characteristics which are general and typical (Pashukanis, 1932). Pashukanis (1932), thus, argued that a pure concept of law devoid of socio-economic formations through historical developments could 
only be a ploy used by the bourgeois jurists to hide the reality of the exploitative nature of society and law, as seen in the capitalist law of private property, leading to unemployment, misery and poverty of the proletariat (Pashukanis, 1932) The reliance therefore on the concept of socio-economic formation in the search for a definition of state and law is crucial in Marxist theory as it provides a basis for a "precise and scientific delineation of the different types of state and the different systems of law" (Pashukanis, 1932:3). Law is therefore a phenomenon of social relationships, as in relations of production and exchange, representing the interest of the ruling class under the protection of organized force. Accordingly, all other areas of law, apart from civil law which constitutes the basic law, are of a subordinate or derivative nature and it is only bourgeois law that creates a legal state and criminal law (Stuchka, 1927). Stuchka's (1927) definition of law is embedded with several errors and loopholes. In the first instance, he thinks of the basic law as civil law which in his view serves as an economic intermediary, relegating all other areas of law to a subordinate level. His definition presupposes the existence of a set of 'law' identified as a basic law and superior to all others also known as law but inferior in nature. This view of law fails to provide a definitive concept of law and his attempt at segregating law into superior and subordinates reduces law into a compartmentalized concept creating confusion both in theory and practice.

Truly, economics is at the base of political, familial and other social relations, as the nature of a state and law are generally determined by economic relations. In the same vein civil law, being part and parcel of law in general, also has its base in economic relations and consist mainly of legislations detailing the confines of economic relations between individuals in a state (Engels, 1888). Law in general has different branches affecting the economy in different ways. Therefore, to equate the basic law to civil law and limit the scope of law to property relations and relations of production is wholly incorrect. The recognition of law as a historical phenomenon, involving class systems, and based on the system of exchange of commodities of equal value eliminates other important values of law, such as its use as a social control mechanism. Further, Pashukanis thought of bourgeois law as one not limited to the facilitation of exchange or property relations between commodity owners but also seeks to entrench unequal distribution of property and supports the monopoly of the capitalist in production (Pashukanis, 1932).

In sum, law is a means of composing and consolidating class society's relationships of production and the social relationships connected with them. These relations are formed with certain ideological views supported by the conscious will of the people expressed through the formulation of various relationships which are shown in the resulting customs and rules. The resulting customs and rules are consequently backed by the ruling class through an organized coercive apparatus such as the courts, police, army, prison guards, court bailiffs (Pashukanis, 1932). Simply put, law becomes meaningless without an apparatus of state coercion, and Lenin (1917) minced no words when he said, bourgeois law is nothing without an apparatus capable of enforcing observation of the norms of law. Accordingly, law in bourgeois society is seen as an instrument of domination and oppression by the ruling class. The description of law in this sense however fails to bring out the true essence of law as the domination and oppression of one by another can exist without law (Fuller, 1949).

In the State and law under socialism, Pashukanis (1936), observed that the practice of socialist law is an intensified struggle and an infliction of heavy blows on the remnants of class enemies. The courts he indicated is a tool of coercion and repression of the enemies of society and that soviet law is used to achieve correct relation between citizens and the socialist state.

Pashukanis' commodity exchange theory identifies law as being independent of the state and exclusively as a thing for the ruling class (Melvin, 1951-1952). Thus, the reduction of law to a state where it is seen as an instrument of class coercion by the ruling class destroys the whole concept of law, its importance and reduces it to a shameful weapon of war, struggle, antagonism and feuds. Further the emphasis on commodity exchange, property relations and individual ownership as core to the theory of law, as championed by Pashukanis, makes the market place the origin of law and ignores other aspects of law and therefore portrays law as a myopic market social being. It appears the Marxist perception of law lacks depth, substance and is very limited in nature. In as much as history is important in the search for an appropriate definition and components of law, historical developments alone cannot define law. The nature of the Marxist concept of law is myopic and fails to see law in its broadest sense well beyond class struggles and property relations. It also fails to consider or deal with what happens beyond exchange relationships and sees law as a system of coercion applied by state apparatus to oppress the masses.

Following from all the propositions, theories and narrative postulations, there seems to be no safe, an all encompassing and exhaustive definition of law acceptable to all schools of thought and jurists. The development and definition of law has over the period been tied to historical development of a society, socio-cultural environment within which each theorist finds himself. One can therefore not disassociate himself from his 
environment in his attempt to find a perfect definition of law. How accurate therefore can one be in his search for a true and an all-encompassing definition of law?

Law can therefore be defined as a system of relationships and behavioral patterns accepted and backed by the will of the people and in accordance of which human conduct is measured, and a deviation of which attracts a certain measure of sanction from society through an authoritative source whose actions are backed by the force and will of the people.

\section{References}

Black, D. J. (1972). The Boundaries of Legal Sociology. The Yale Law Journal, 81(6), 1086-1100. http://dx.doi.org/10.2307/795221

Coase, R. H. (1960). The Problem of Social Cost. The Journal of Law and Economics. http://dx.doi.org/10.1086/466560

Collins English Dictionary. (2003). HarperCollins Publisher. Retrieved from http://www.thefreedictionary.com/Marxist+Theory

Durkeim. E. (1953). Sociology and Philosophy. The Free Press.

Ehrlich, E. (1916). Montesquieu and Sociological Jurisprudence. Harvard Law Review, 29(6), 582-600. http://dx.doi.org/10.1017/CBO9780511815546.016

Engels, F. (1888). Ludwig Feuerbach and the End of Classical German Philosophy. Retrieved from https://www.wsws.org/IML/ludwigfeuerbach/index.shtml

Frankford, D. M. (1995). Social Structure of Right and Wrong: Normativity without Agents. Law \& Social Inquiry, 20(3), 787-803. Retrieved from http://www.cshp.rutgers.edu/Downloads/CV/David_Frankford.pdf

Fuller, Lon L., Pashukanis, \& Vyshinsky. (1949). A Study in the Development of Marxian Legal Theory. Michigan Law Review, 47(8), 1157-1166. http://dx.doi.org/10.2307/1284239

Hobbes, T. (1909). Leviathan (pp. 97-98). Oxford: Oxford University Press.

Holmes, O. W. (1997). The Path of the Law. Harvard Law Review, 110(5), 991-1009. http://dx.doi.org/10.2307/1342108

Kelsen, H. (1945). General Theory of Law and State (trans.: A. Wedberg). Cambridge, MA: Harvard University Press.

Kelsen, H. (1957). 'Science and Politics', in what is Justice? Justice, Law, and Politics in the Mirror of Science. Berkeley: University of California Press.

Kelsen, H. (1992). Introduction to the problems of Legal Theory (trans.: Bonnie Litschewski Paulson \& Stanley L. Paulson). Oxford: Clarendon Press.

Kronman, A. T. (1985). Contract Law and the State of Nature. Journal of Law, Economics and Organization, 1(1), 5-32.

Lenin, V. I. (1895). The Economic Content of Narodnism. LCW, 1, 419.

Lenin, V. I. (1917). State and the Revolution. $L C W, 25,471$.

Malinowski, B. (1942). A New Instrument for the Interpretation of Law Especially Primitive2 Law. Guild Rev, 1. Retrieved from http://heinonline.org

Melvin, G. (1951). Observations to Industrial Location. South Econ. Jour., 18, 225-228. http://dx.doi.org/10.2307/1054306

Melvin, G. (1952a). Integrating the leading theories of plant location. South Econ. Jour., 19, 526-538.

Melvin, G. (1952b). Size and shape of the market area of a firm. South Econ. Jour., 19, 37-50. http://dx.doi.org/10.2307/1053969

Michelman, F. I. (1977). States' Rights and States' Roles: Permutations of Sovereignty in National League of Cities v. Usery 86 Yale L.J., 1165, 1167. http://dx.doi.org/10.2307/795704

Ologies \& Isms. (2008). The Gale Group Inc.

Pashukanis, E. (1932). The Marxist Theory of State and Law. Retrieved from https://www.marxists.org/archive/pashukanis/index.htm 
Pashukanis, E. (1936). State and Law under Socialism. Retrieved from http://www.home.law.uiuc.edu/ pmaggs/pashukanis.htm

Paulson, S. L. (1992). Kelsen's Legal Theory: The Final Round. Oxford Journal of Legal Studies, 12(2), 265-274. http://dx.doi.org/10.1093/ojls/12.2.265

Pound, R. (1943). The foundation of law. The American University Law Review, 10. Retrieved from http://www.aulawreview.org/pdfs/10/10-2/pound.pdf

Random House. (2010). Random House Kernman Webster's College Dictionary. K. Dictionaries Ltd.

Spencer. H. (1882). Principles of Sociology (Vol. II). Retrieved from http://www.jstor.org/sici?sici=0002-9602(189703)2\%3A5\%3C741\%3ATPOSVI\%3E2.0.CO\%3B2-V

Stuchka, P. I. (1927). A Course on Soviet Civil Law (Vol. 1).

The Constitution of Australian. (1900).

The Constitution of Ghana. (1992).

The Constitution of Nigeria. (1999).

The Constitution of South African. (1996).

The Constitution of the United States. (1790)

Turk, A. T. (1976). Law as a Weapon in Social Conflict. Social Problems, 23(3), 276-291. http://dx.doi.org/10.2307/799774

Vaihinger, H. (1935). The Philosophy of 'As if' (trans.: C. K. Ogden, 2nd ed.). London: Kegan Paul, Trench, Trubner \& Co.

Weber, M. (1958). Essays in Sociology (trans.: H. Gerth, \& C. Wright Mills). New York: Oxford University Press.

\section{Cases}

Begum Nusrat Bhutto v. The Chief of the Army Staff \& Federation Pakistan, PLD1977 SC 657

Madzimbamuto v. Ladner Burke (1978) 3 WLR 1229.

Miss Asma Jillani v. Government of Punjab \& Anor, P L D 1972, 139

The State v. Dosso, P L D 1958 S C (Pak.) 533

Uganda v. Commisioner for Prisons, Ex parte Matovu, 1966 E.A

\section{Note}

Note 1. Collins English Dictionary, 2003, HarperCollins Publisher.

\section{Copyrights}

Copyright for this article is retained by the author(s), with first publication rights granted to the journal.

This is an open-access article distributed under the terms and conditions of the Creative Commons Attribution license (http://creativecommons.org/licenses/by/3.0/). 